ISSN 2338-4778 (Print)

ISSN 2548-4192 (Online)

Volume 8, Number 2, December 2020

pp. $471-482$

\title{
Students' Collaborative Writing Method in Pre-Writing Phase
}

\author{
Kartika Dewi Rahayu ${ }^{1}$, Dyah Anggraeni Novitasari², Rikha Mirantika ${ }^{3}$ \\ Kartikadewi45913@gmail.com \\ 1,2,3Universitas Singaperbangsa Karawang
}

Received: 23 October 2020 Accepted: 29 November 2020

DOI: $10.24256 /$ ideas.v8i2.1615

\begin{abstract}
In a pre-writing phase, students need their creativity to put ideas into words. Students need to use what they listen to and what they read as information to start to write. This study reports the findings on the implementation of the collaborative writing method by an English teacher in teaching writing in the pre-writing phase and students' perceptions in the pre-writing phase using the collaborative writing method. This research uses descriptive qualitative research. Participants in this study were nine students and teachers at SMK in Karawang. Data collection was carried out through reflective journals, interviews, and documentation. The results of the study found that the collaborative writing method was an effective method for use in writing classes. The collaborative writing method can be implemented in teaching writing in the pre-writing phase. The results showed that the students were very enthusiastic, interested, and made the learning process fast. Students' perceptions of learning to write in the pre-writing phase using the collaborative writing method are that students find it easier to express their thoughts in the learning process and there is cooperation in groups that accelerate the time when doing their assignments helps them during the learning process.
\end{abstract}

Keywords : pre-writing phase; students collaborative; writing collaborative method.

\section{Introduction}

Teaching writing is a complex process. Having students to use their ability to transform ideas into concrete organized sentences in a piece of paper which requires lots of creativity is a long process. Especially in Indonesia in which students have low motivation in reading. Indonesian's reading interest is in sixth rank from behind which is in the same level with some small countries like Albania and Peru.

In writing, there are some steps to follow, they are planning, drafting, editing, and final version. The step which often underestimated is the planning step. The 
Kartika Dewi Rahayu, Dyah Anggraeni Novitasari, Rikha Mirantika

Students' Collaborative Writing Method in Pre-Writing Phase

pre-writing phase is the most neglected stage, whereas it is impossible to have a good writing if they do not have a good start in planning. If writing teachers provide many pre-writing activities, it will help students to get language topics faster and more personal.

In the pre-writing process itself, there are several stages to carry out, namely brainstorming, mapping/grouping, and free writing (Ashwell, 2000). Oshima \& Hogue (2007) said that there are two steps in pre-writing activities, namely choosing and narrowing topics, and brainstorming. The choosing and narrowing topics step is a step in which student have to try to avoid writing in general and stay focused on the right topic. The brainstorming step requires students to get ideas related to topics Students combine their ideas with existing writing know-how. In brainstorming, three strategies can be used, namely listing (Listing can be a conceptual strategy that allows you to organize from the topic you choose, and quickly list whatever words or considerations you consider), free writing (free writing is to create as much thought as possible and write it down without stressing conformity, the structure of the language, grammar, sensible, or organization.), and clustering/mapping (write your topic in the center of your paper and draw a balloon around it. This is usually your focus or center, on the balloon. Write down what you think in a center balloon at that point. Think of each of these ideas and make more balloons around them).

Collaborative learning is an important pedagogical method to make second-language learning more successful (Watanabe \& Swain, 2007). Writing collaborative method is a technique that comes from the concept of collaborative learning based on the work of Vygotsky. Human development and learning take place in a social context (Cameron, 2001: 6). Meanwhile, Fung (2006) states that collaborative writing is the sharing of responsibility for the production of a single piece of work in which everyone has a part to play in the whole process of writing. In other words, collaborative writing focuses on the whole process of writing a single text through a shared endeavor. In line with this, writing collaborative method refers to a situation in which students are put in groups to produce a text and it is hoped that they can learn from their peers in the groups. Although there are some advantages of using collaborative writing which is stated by researchers, those advantages are only from the view of students' writing products. On the contrary, Fung (2006: 5-7) categorizes the advantages of writing collaborative method into three different views: social, cognitive, and practical.

In the social view, the most important benefit of writing collaborative method is group interaction. Students can learn more about writing by talking and listening to their peers. In the cognitive view, collaboration increases the awareness of the audience. In writing collaborative method, peers become an immediate audience while the text is being constructed. Finally, in a practical view, writing collaborative method generally improves individual writing. It also furthers the students' independence because they may learn about the knowledge of writing from their peers in the group. 
ISSN 2338-4778 (Print) ISSN 2548-4192 (Online)

This research focuses on learning experiences using the writing collaboration method. As known that writing collaborative method both in pairs and in groups involves two or more students to produce articles. This method is useful for student writing in terms of idea creation and social interaction. Collaborative strategies in the planning stages of writing can facilitate meaningful interactions among diverse English as Foreign Language (EFL) learners; this might result in helping students learn to write. By contrast, the researcher found that students are very confused when writing themselves. Students also find it difficult to develop ideas in writing. On the other hand, the result of the interview on the pre-observation shows that some students find difficulty in building ideas when they want to write. Therefore, the researcher uses the pre-writing strategy in gathering information and in reflecting it at the early stage of writing.

Regarding the importance of writing skills in English learning, some scholars conduct the study on writing. Such as Sukirman (2016) conduct the study on writing entitled Using writing collaborative method in Teaching Writing. The results of this study show that writing collaborative method has many advantages as well as disadvantages. For the advantages; promotes; 1) social skills development, 2) stress reduction and time-saving benefits, 3) motivational effects, 4) improvement in the content of their writing, and 5) gains in grammatical and structural proficiency. Then, the disadvantages deal with; 1) increases stress, 2) logistical problems, 3) target language usage, 4) conflict with personal learning style, and 5) issues of fairness. Moreover, the result also shows that writing collaborative method strategy has three types of tasks that can be designed for students. They are; 1) higher-order thinking tasks, 2) division of labor tasks and 3) specialist or expertise-based tasks. Additionally, it also has many strategies that can be utilized in teaching writing; 1) group single author writing; 2) sequential single writing; 3) parallel writing (divided into two types; horizontal division parallel writing and stratified division parallel writing); 4) reactive writing; and 5) mixed-mode writing.

On the other hand, Chen \& Yu (2019) conduct the study entitled Implementing Writing Collaborative Method in Teacher-Centered Classroom Context: Student Belief and Perception. The results show that writing collaborative method was perceived as beneficial for improving writing, providing the opportunity to pool ideas, and having positive emotional (e.g., reducing stress) and social effects (e.g., building a network). The participants were also concerned that it limited their actual learning and thinking, increased the difficulty of dealing with various views, and provoked negative emotions (e.g., loss of self-confidence) and social effects (e.g., feeling isolated). Besides, the analysis of the students' beliefs about English writing before and after writing collaborative method revealed their reconsideration of what good English writing involved (from focusing on vocabulary, sentences, and grades to understandable texts), the purpose of English writing (from exam-oriented purposes to communication purposes), the focus in 
English writing (from product writing to process writing) and the nature of English writing (from individual work to teamwork).

Based on the explanation, the problem of this research as follows, In what ways does the teacher implement the collaborative writing method in the pre-writing phase, and What are students' perceptions of the collaborative writing method in the pre-writing phase.

This study aims to examine how the teacher implements the writing collaborative method and to examine the students' perceptions of the collaborative writing method in the pre-writing phase.

\section{Method}

This study used a qualitative design because in gathering data this research wants to know what students' perceptions of learning by using the collaborative writing method in a pre-writing phase can help students exchange ideas or discuss with friends in English writing assignments after which the results generated from data collection will be explained using descriptive methods. A qualitative design is an approach used to discuss phenomena about what is discussed by research on perceptions and motivations through descriptions in the form of words and languages, in certain natural contexts and by utilizing various natural methods (Kabir, 2016).

The location of this research is in a vocational school in Karawang. Researchers chose these schools because they have access to teachers and know the characteristics of students in teaching training. There were about thirty-five students in this study involving students who were taken from one of the students of class XI. For participants in this study, the researcher will select nine students to observe their students' perceptions of how the teacher applies collaborative writing methods in teaching writing at the pre-writing stage. These nine students will be given questions or interviews about how the teacher applies collaborative writing methods in teaching writing at the pre-writing stage. Meanwhile, researchers act as teachers and observers.

The data in this study was collected through reflective journal, interview guideline, and documentation. The researcher acted as the teacher and discussed her teaching experience of writing, especially in the pre-writing phase by using the collaborative writing method in the reflective journal.

The structured interview was used to interview students to know their perception of the use of writing collaboration techniques. In conducting the interview, the researcher acts as an interviewer that interviews some students. Then, the researcher collected lesson plans and syllabus that were used as the reference for conducting the process of online learning activities.

The data obtained were analyzed by using Miles and Huberman's methods of data analysis. There are three steps of data analysis that can be explained as follow:

Data reduction here means the process of transforming the data obtained and selecting that data by focusing on the teacher's utterances that are used to instruct 
the students and also on the students' responses toward those instructions. This step is important to make sure that there is no useless data included in the data.

Data display in this context means the process of data classification. It is classified based on Brown and Levinson's politeness strategy including positive politeness strategy, negative politeness strategy, bald-on record strategy, and off-record indirect strategy. On the other sides, the students' responses also classify into three categories: good responses, poorly good responses, and bad responses.

Drawing conclusion and verification here means the process of describing and interpreting the data displayed. After the data described and interpreted, the researcher drew the conclusion and verification of the teacher's politeness strategy, especially in giving directions that applied in the whole classroom activities and also the students' responses toward it.

In short, the data collected were analyzed through three steps. First, selecting data obtained from student interviews and reflective journal of teacher experiences during teaching so that researcher more easily to analyze the data. After that, the researcher focuses on the data by referring to the formulation of the research question. Finally, the researcher draws the conclusion into basic of overall analysis.

\section{Results and Discussion}

Steps in Implementing the Collaborative Writing Methods in the Pre-writing Phase

The result shows that there are some steps in implementing collaborative writing method in the pre-writing phase, they are: 1) Teacher instructs the students to make group consist of three students, 2) Teacher gives the material, example of the topic that can be chosen by the students to write a text in the pre-writing phase, and also gives the students the assignment to write a text by following the steps of pre-writing, 3) Teacher asks the students to collect the result of their assignment.

In the first step, the teacher instructs students to create groups in the WhatsApp group; each group consists of 3 students and provides material about the pre-writing phase, step of pre-writing phase, and examples.

In the second step, the teacher gives an example of the topic for students' descriptions when they choose a topic with their group that can be used as a topic in writing in the pre-writing phase through WhatsApp groups. Then, students discuss to determine the topic they will choose. Three groups discuss the initial preparation of writing at the pre-writing stage, which in the form of selecting and narrowing the topic then goes to the brainstorming stage that in this activity to develop the topic to be written and ideas about the chosen topic. In brainstorming, there are also three useful methods, namely list, mapping/grouping, and free writing then write it down on a piece of paper and they discuss in the WhatsApp group each group to write in the pre-writing phase, namely selecting and 
Kartika Dewi Rahayu, Dyah Anggraeni Novitasari, Rikha Mirantika

Students' Collaborative Writing Method in Pre-Writing Phase

narrowing the topic, and brainstorming (and list, mapping/grouping, and free writing).

In the final step is the students gather the results of their group discussions related to the chosen topic and write brainstorming (list, freewriting, and grouping/mapping).

The steps explained above, in line with Barkley (2012: 4) who explained that there are seven steps in implementing the collaborative writing method, they are: 1) the teacher divides students into groups, each group consisting of 3 people. Then the teacher gives material about pre-writing, 2) the teacher presents several topics that can be used as topics in writing in the pre-writing phase, 3) the group determines the topic to be chosen, 4) the group discusses the initial preparation of writing in the pre-writing phase, which is in the form of choosing and narrowing topics then goes to the brainstorming step that in this activity to develop the topic to be written and ideas about the chosen topic. In brainstorming also has three useful methods, namely listing, mapping/clustering, and free writing then writing it down on a piece of paper, 5) the group prepares the paper again to write in the pre-writing phase, namely choosing and narrowing a topic, brainstorming (listing, mapping/clustering, and free writing), 6) each student writes the results of the discussion on the paper in accordance with the contents of the guidelines that have been made (before writing a sentence each student must discuss it with a group of friends, and 7) after completion, the group submits their work to the teacher to get an assessment. The paper is used as a guideline in writing collaboratively.

In the conclusion, there are three steps in implementing collaborative writing method in pre-writing phase: Teacher instructs the students to make group consist of three students, the teacher gives the material, example of the topic that can be chosen by the students in order to write a text in the pre-writing phase, and also gives the students assigned to write a text by following the steps of pre-writing, and the teacher asks the students to collect the result of their assignment.

\section{Students' Perceptions on Collaborative Writing Methods in the Pre-writing Phase}

The researcher interviews with nine students. The interview here related to students' perceptions of collaborative writing methods in the pre-writing phase. There are several results from this research, such as 1) collaborative writing method promotes the students' interest, 2) collaborative writing method helps them to write, especially in the pre-writing phase, 3) collaborative writing method promotes good communication among students, 4) the students find the difficulty when they have different perspectives related to the topic discussed, 5) some of the students feel so hard in doing communication, especially when they were doing online discussion, and 6) some of the students find a little difficulty in the process of writing.

a. Collaborative writing method promotes the students' interest

To address the first finding, the researcher involves the results of interviews toward nine students related to their perception on the collaborative writing 
method in the pre-writing phase. The results show that R1 said that "Saya pribadi cukup menyukainya, karena kita bisa belajar bersama-sama kak". From that perception it is know that she likes learning to write in the pre-writing phase using the collaborative writing method because with the collaborative writing method she can learn together with friends in her group. While R5 argued "Prewriting dengan menggunakan metode writing collaboration ini seru, karena bisa saling mengeluarkan pendapat satu sama lain". In other words, learning to write in the pre-writing phase by using the collaborative writing method is exciting because she can express her opinions with one another in her group friends. Then, in R6 opinion "Menyenangkan sekali, dan juga sangat memudahkan bagi saya. Melalui writing collaboration, saya dapat langsung bertanya kepada teman satu grup dengan saya tentang bagian yang tidak saya pahami, dan juga saat mengerjakan tugas jadi lebih semangat rasanya kak!". Regarding the opinion of R6, learning to write in the pre-writing phase using the collaborative writing method was very fun and very easy for her. Through collaborative writing, she can immediately ask friends in the group with her about the part that is not understood and so very excited when she was while doing assignments.

Moreover, R7 said that "Menyenangkan dan sangat mudah dipahami karena terkonsep dengan baik". In the simple sentence, collaborative writing methods make learning more fun and very easy to understand because the material is well conceptualized. She felt it was better to study in groups than individuals because she and other members in her group could share ideas with one another. Those perception also supported by R8 who tells "Menulis pre-writing dengan menggunakan metode writing collaboration sangat membantu saya dan teman-teman mengerjakan tugas, saya menyukai metode ini". From that perception it can be said that she liked learning to write in the pre-writing phase using the collaborative writing method, in the process of learning to write pre-writing using the collaborative writing method; it was very helpful for R8 and her classmates while doing their assignments.

b. Collaborative writing method helps them to write, especially in pre-writing phase

To address the second finding, the researcher includes the results of interview toward nine students related to their perception on the collaborative writing method in pre-writing phase. The results show that R1 said that "Bisa membantu kak, karena setiap anggota akan menerapkan secar bertahap agar yang lain mudah mengerti". From that perception, the method of collaborative writing can help the student in learning to write in the pre-writing phase because of the cooperation that accelerates the time of work. In R3, R4, and R7 opinions, "jika ada yang kesulitan bisa berdiskusi bersama-sama sehingga dapat membantu dalam proses pembelajaran menulis". In other word, collaborative writing method helps the student to face the difficulty in the process of writing. 
The R5, R6, and R8 perceive "memudahkan kita untuk menciptakan banyak ide dan mengembangkannya untuk membuat tulisan yang lebih baik". Regarding to the opinion of R5, R6, and R8, collaborative writing method assist the students in creating and developing idea to produce a great writing. Moreover, R9 believe "metode writing collaboration diterapkan, supaya memudahkan dan menghemat waktu". In the simple sentence, collaborative writing method is useful for assisting students learn to write and for making time be more effective.

c. Collaborative writing method promotes a good communication among students

To address the third finding, the researcher includes the results of interviews toward nine students related to their perception on the collaborative writing method in the pre-writing phase. The results show that R1 and R2 said "bisa menjalin komunikasi dengan anggota serta berpartisipasi dalam diskusi kelompok". Based on R1 and R2 opinion it's known that collaborative writing methods can establish group communication and arise the participation of members in the process of writing.

d. The students find the difficulty when they have different perspectives related to the topic discussed

To discuss the first finding, the researcher includes interview results of nine students related to their perception of the collaborative writing method in the prewriting phase. The results show that R5 perceive "akan sulit jika terjadi perbedaan pendapat antara anggota nya". Related to that perception the problem comes when there are some differences of opinions of each member of the group.

e. Some of students feel so hard in doing communication, especially when they were doing online discussion

To discuss the second finding, the researcher includes interview results of nine students related to their perception of the collaborative writing method in the prewriting phase. The results show that R6 said, "Karena saya mencoba metode writing collaboration nya online, jadi agak sulit dalam hal komunikasi". From that perception it is known that she tried her collaborative writing method via online it became rather difficult in terms of communication.

f. Some of students find a little difficulty in the process of writing

To discuss the third finding, the researcher includes interview results of nine students related to their perception of the collaborative writing method in the prewriting phase. The results show that R7 argued "sedikit ribet karna harus melalui beberapa tahapan seperti membuat mapping". Based on R7 opinion it is a bit complicated in her learning because she has to go through several stages in his material, such as mapping.

Therefore the implementation of the collaborative writing method in the pre-writing phase has advantages and disadvantages. It is in line with Fung (2006: 5-7) who categorizes the advantages of collaborative writing into three different views: social, cognitive, and practical. In the social view, the most 
important benefit of collaborative writing is group interaction. Students can learn more about writing by talking and listening to their peers. Besides that, during the collaborative, students are certainly faced with different opinions from the members of the group. This difference of opinions also improves students' problem-solving ability as they learn to reach consensus. In the cognitive view, collaborative increases the awareness of the audience. In collaborative writing, peers become an immediate audience while the text is being constructed. It makes the students more alert to analytical and critical thinking. Finally, in a practical view, collaborative writing generally improves individual writing. It also furthers the students' independence because they may learn about the knowledge of writing from their peers in the group. In contrast, there also disadvantages of writing collaboration method, such as 1) the difficulty of getting a colleague who can work together, 2) in group work often there are too many alternatives or confusing suggestions for improvement, 3) taking a lot of time from teachers and students (Alwasilah, 2000).

Regarding the importance of writing skills in English learning, some scholars conduct the study on writing. Such as Sukirman (2016) conduct the study on writing entitled Using Collaborative Writing in Teaching Writing. The results of this study show that collaborative writing has many advantages as well as disadvantages. For the advantages; promotes; 1) social skills development, 2) stress reduction and time-saving benefits, 3) motivational effects, 4) improvement in the content of their writing, and 5) gains in grammatical and structural proficiency. Then, the disadvantages deal with; 1 ) increases stress, 2) logistical problems, 3) target language usage, 4) conflict with personal learning style, and 5) issues of justice.

In the conclusion, the students' perceptions about collaborative writing methods in the pre-writing phase, the students perceive that collaborative writing method promotes the students' interest, collaborative writing method helps them to write, especially in the pre-writing phase, collaborative writing method promotes good communication among students, the students find the difficulty when they have different perspectives related to the topic discussed, some of the students feel so hard in doing communication, especially when they were doing online discussion, and some of the students find a little difficulty in the process of writing.

\section{Conclusion}

Based on the findings and discussion, we can sum up two points here. The first is that the writing collaboration method can be implemented in teaching writing in the pre-writing phase. The teacher managed to carry out writing class using the writing collaboration method. The students have understood the material delivered 
Kartika Dewi Rahayu, Dyah Anggraeni Novitasari, Rikha Mirantika

Students' Collaborative Writing Method in Pre-Writing Phase

by the teacher about pre-writing. The students also said that the implementation of the writing collaboration method was needed in the pre-writing learning process. Students could discuss together to solve problems in pre-writing learning difficulties, and students feel more confident to express their opinions, find solutions together and it makes the learning process faster and easier.

The second conclusion is students' perceptions about learning by using the method of collaborative writing in the process of writing in the pre-writing phase. The students perceive that 1) collaborative writing method promotes the students' interest, 2) collaborative writing method helps them to write, especially in the pre-writing phase, 3) collaborative writing method promotes good communication among students, 4) the students find the difficulty when they have different perspectives related to the topic discussed, 5) some of the students feel so hard in doing communication, especially when they were doing online discussion, and 6) some of the students find a little difficulty in the process of writing.

It can be concluded that students' perceptions of learning by using collaborative writing methods in the writing process in the pre-writing phase are all students feel more confident to express their thoughts, feel more active, the learning process is more interesting and beneficial to them during the learning process, especially in the pre-writing phase.

It can be implicated from the result theoretical and practical that the application of the collaborative writing method in teaching writing in the pre-writing phase has a positive perception because all students feel it is easier to express their thoughts in the learning process and establish cooperation in groups that accelerates the time while working on their assignments in learning to write in the pre-writing phase using the collaborative writing method.

In line with the research findings, it is recommended that language institution teachers can use a variety of texts used in different content. Future researchers are expected to make practical contributions to learning methods, especially in English education. Besides, the knowledge of researchers that this research will have any deficiencies that I hope that deficiencies can be given a solution by the next researcher who wants to research collaborative writing methods. This method can be applied to other classes that have similar problems.

\section{References}

Abrori (2018). Deane, P., Odendahl, N., Quinlan. T., Flowles, M., Welsh, C., \& Tatum, J. B. (2008). Improving Reading Literacy Strategy through Seven Programs of Reading Interest containing Da'wah Message. Retrieved June 9,2020, from https://attarbiyah.iainsalatiga.ac.id/index.php/attarbiyah/article/view/2286

Ashwell, T. (2000). Patterns of teacher response to student writing in a multiple-draft composition classroom: is content feedback followed by form feedback the best method? Journal of Second Language Writing9 (3), 227-257. 
Cameron Lynne. (2001). Teaching Language to Young Learners. Cambridge: Cambridge University Press.

Dobao, A. F., \& Blum, A. (2013). Collaborative writing in pairs and small groups: Learners' attitudes and perceptions. System, 41, 365-378. doi:10.1016/j.system.2013.02.002.

Dobao, A. F. (2012). Collaborative writing tasks in the L2 classroom: Comparing group, pair, and individual work. Journal of Second Language Writing, 21(1), 40-58.

Donato, R. (2004). Aspects of collaboration in pedagogical discourse. Annual review of applied linguistics, Cambridge: Cambridge University Press. pp. 284-302.

Dornyei, Z. (2001). Motivational strategies in the language classroom. Cambridge: Cambridge University Press.

Fung, Mei Yong. (2006). The Nature and Dynamics of Collaborative Writing in a Malaysian Tertiary ESL Setting. New Zealand: Massey University Press.

Furwana, D., \& Syam, A. (2019). Improving Students' Writing Skill on Descriptive Text By Estafet Strategy of the Eleventh Year Students of SMA 4 Palopo. IDEAS: Journal on English Language Teaching and Learning, Linguistics and Literature, 7(1). doi:https://doi.org/10.24256/ideas.v7i1.722

Grief, S., Meyer, B. and Burgess, A. (2007). Effective teaching and learning: Writing. London: NRDC.

Hammer, Jeremy. 2007. The Practice of Language Teaching. Cambridge : Longman.

Huff, R., \& Kline, C.(1987). The contemporary writing curriculum. Teachers College Press, New York.

Majchrzak, 0. (2018). Learner identity and learner beliefs in EFL writing. New York, NY: Springer.

Mar'at. (1991). Sikap manusia, perubahan, serta pengukuran. Jakarta. Ghalia Indonesia.

Masruddin, M., \& Kurnia, K. (2018). IMPROVING STUDENTS WRITING SKILL BY USING PICTURE AT THE TWELFTH YEAR STUDENTS OF SMA PESANTREN MODERN DATOK SULAIMAN PUTRA PALOPO. IDEAS: Journal on English Language Teaching and Learning, Linguistics and Literature, 3(2). doi:https://doi.org/10.24256/ideas.v3i2.152

McDoniel, Misty. 2008. "Process Approach to Writing." http://voices, yahoo.com/process-approachwriting-2101022.html. Retrieved on February 29, $2011 ; 15,02$.

Miles, Mattew B dan Amichael Huberman. 2007. Analisis Data Kualitatif Buku Sumber tentang Metode-Metode Baru. Terjemahan Tjetjep Rohendi Rohisi. Jakarta: Universitas Indonesia.

M, J. (2019). Teaching Strategies in Writing Class at Palopo Cokroaminoto University. IDEAS: Journal on English Language Teaching and Learning, 
Kartika Dewi Rahayu, Dyah Anggraeni Novitasari, Rikha Mirantika

Students' Collaborative Writing Method in Pre-Writing Phase

Linguistics and Literature, 7(2). doi:https://doi.org/10.24256/ideas.v7i2.1028

M, J. (2019). The Students' Ability in Writing Descriptive Text through Outdoor Activity at Palopo Cokroaminoto University. IDEAS: Journal on English Language Teaching and Learning, Linguistics and Literature, 7(1). doi:https://doi.org/10.24256/ideas.v7i1.721

Oshima, A \& Hogue, A. (2007). Introduction to Academic Writing. NewYork: Pearson Education, Inc.

Syafii, M. (2019). Improving the Quality in Writing Descriptive Texts of Madrasah Aliyah Students through Directed Writing Activity Strategy. IDEAS: Journal on English Language Teaching and Learning, Linguistics and Literature, 7(2). doi:https://doi.org/10.24256/ideas.v7i2.1027 